\title{
LAND SUITABILITY EVALUATION OF WADI EL ASSIUTY AREA, EASTERN DESERT OF ASSIUT GOVERNORATE, EGYPT, USING REMOTE SENSING DATA Fahmy, F.M.
}

\author{
Soils, Water and Environ. Res. Institute, Agric. Res. Centre, Giza, Egypt.
}

\section{ABSTRACT}

The study area is located in the Eastern desert part of the Nile valley of Assiut Governorate, and covers about 56670 feddans. The objective of this study is to evaluate the soils of Wadi El Assiuty for the agricultural development using remote sensing data. The obtained physiographic units in the study area and the associated soils that represented by ten soil profiles were attributed as:

(1) Gently undulating to undulating oldest alluvial terraces which include the taxonomic units of Typic Clacigypsids, loamy-skeletal, mixed, hyperthermic as dominated soils, and Typic Clacigypsids, coarse-loamy, gypsic, hyperthermic, as minor soils.

(2) Almost flat to gently undulating old alluvial terraces have the taxonomic units of Typic Haplocalcids, sandy-skeletal, mixed, hyperthermic as dominant soils, while Typic Clacigypsids, coarse-loamy, mixed,hyperthermic, as minor soils.

(3) Young alluvial terraces includes Typic Haplocalcids, sandy, mixed, hyperthermic as dominant soils.

(4) Wadi bottoms includes the taxonomic units of Typic Torriorthents, sandy-skeletal, mixed, hyperthermic and Typic Torriorthents, sandy, mixed, hyperthermic.

(5) Dissected Rockland which are not promising area for the agricultural land use.

The current and potential suitability of the studied soils for irrigated agriculture were estimated. The obtained results indicate that all soils in its present condition have no to slight intensity of limitations for wetness, soil depth, calcium carbonate and gypsum contents. The soil texture including gravel, salinity and alkalinity, and soil topography are the most effected soil limitations. The obtained current suitability classes are dominated by the marginally suitable one (S3), with exception the currently not suitable (N1) of the oldest terraces soils. All the studied soil profiles can be potentially classified as moderately suitable (S2), which refers to its suitability after major soil improvements.

Key words: physiographic units, remote sensing data and land evaluation. INTRODUCTION

The task of a soil survey is to provide soil information for either general purposes or for a specific use. In the past, surveyors based their approach on the qualitative analysis of the landscape either by physiographic analysis or by aerial photographic interpretation or both. These were all attempts to enrich the soil information through the use of exogenous data. The classical techniques are based on the empirical-deterministic models that originated from Jenny's (1941) Factors of Soil Formations (Jenny, 1941) mathematical function of soil formation is expressed as: $\mathbf{S}=\mathbf{f}(\mathbf{c l}, \mathbf{o}, \mathbf{r}, \mathbf{p}, \mathbf{t})$, where $S$ is some soil properties as a function of

Fayoum J. Agric. Res. \& Dev., Vol. 29, No.2, July, 2014 
Fahmy, F.M.

the factors: cl as climate, $\mathrm{o}$ as organisms, $\mathrm{r}$ as relief, $\mathrm{p}$ as parent material, and $\mathrm{t}$ as time. The CLORPT function stimulated numerous studies, especially on the effects of relief and time factors. Conventional soil survey is also based on the soil landscape equation or concept (Hudson, 1992). The ability of soil scientists to conduct soil surveys accurately and efficiently is largely limited by two major factors, the polygon-based mapping practice and the manual map production process. The polygon-based mapping practice is based on the discrete conceptual model (Zhu, et al. 2001), which limits soil scientist's ability to produce accurate soil maps. Under this model, soils in the field are represented through the delineation of soil polygons. With each polygon depicting the spatial extent of a particular soil class (single-component mapping unit) or a group of commonly found classes (multiple-component mapping unit).

Land information system is based on the application of reliable remote sensing data as well as using international modern systems for the assessment of landscape features and their soil attributes. This approach will simplify the management of the natural resources and monitoring the environmental changes. Accordingly, remote sensing data are highly required for setting up database of land information system which mainly based on physiographic analysis. Goosen (1967) stated that physiography is the description of physical earth surface features, including the processes responsible for parent material development.

This physiographic approach can provide a good basis for explaining geomorphology through aerospace image interpretation. According to Afify (2009), this physiographic approach is highly applicable for tracing the landscape genesis and is valuable for facilitating the clue to define the land attributes, which associated with different physiographic units as reflected by their spectral signatures. Rashed et al. (2006) mentioned that, remote sensing is the acquisitioned data about an object or by a sensor that is far from the object using satellite platforms. They added that, Geographic Information System (GIS) is computer-based systems that are used to store, manipulate and display large amount of data that have been encoded in digital form. It constructs some of data bases and combines them rapidly in multitude of combinations in proper outputs guiding the users for the processes of management, planning, development, monitoring, controlling and decisions making. Field investigations based on the analysis of satellite image and GIS produce relatively cheap, fast and accurate maps.

The objectives of this study were to identify the landscapes and their soil attributes in an area that has important situation for the environmental and demographic development in Egypt. This purpose based on producing a physiographic-soil map using space images interpretation for tracing promising areas in the eastern desert adjacent to the old cultivated areas to be under use for agricultural development. Mapping the relationship between land units in the study area associated with their land potentialities for planting different crops can help for tracing an extra promising area in the same region.

Fayoum J. Agric. Res. \& Dev., Vol. 29, No.2, July, 2014 
LAND SUITABILITY EVALUATION OF WADI EL ASSIUTY 68 MATERIALS AND METHODS

The studied area is located at about $375 \mathrm{~km}$ south of Cairo in the eastern desert adjacent to the old cultivated land in Assiut Governorate. The projected of coordinated location of the study area is from $27^{\circ} 11^{\prime} 15^{\prime \prime}$ to $27^{\circ} 20^{\prime} 51^{\prime \prime}$ North and from $31^{\circ} 11^{\prime} 39^{\prime \prime}$ to $31^{\circ} 20^{\prime} 25^{\prime \prime}$ East (Map 1). The area under study covered about 56670 feddans.

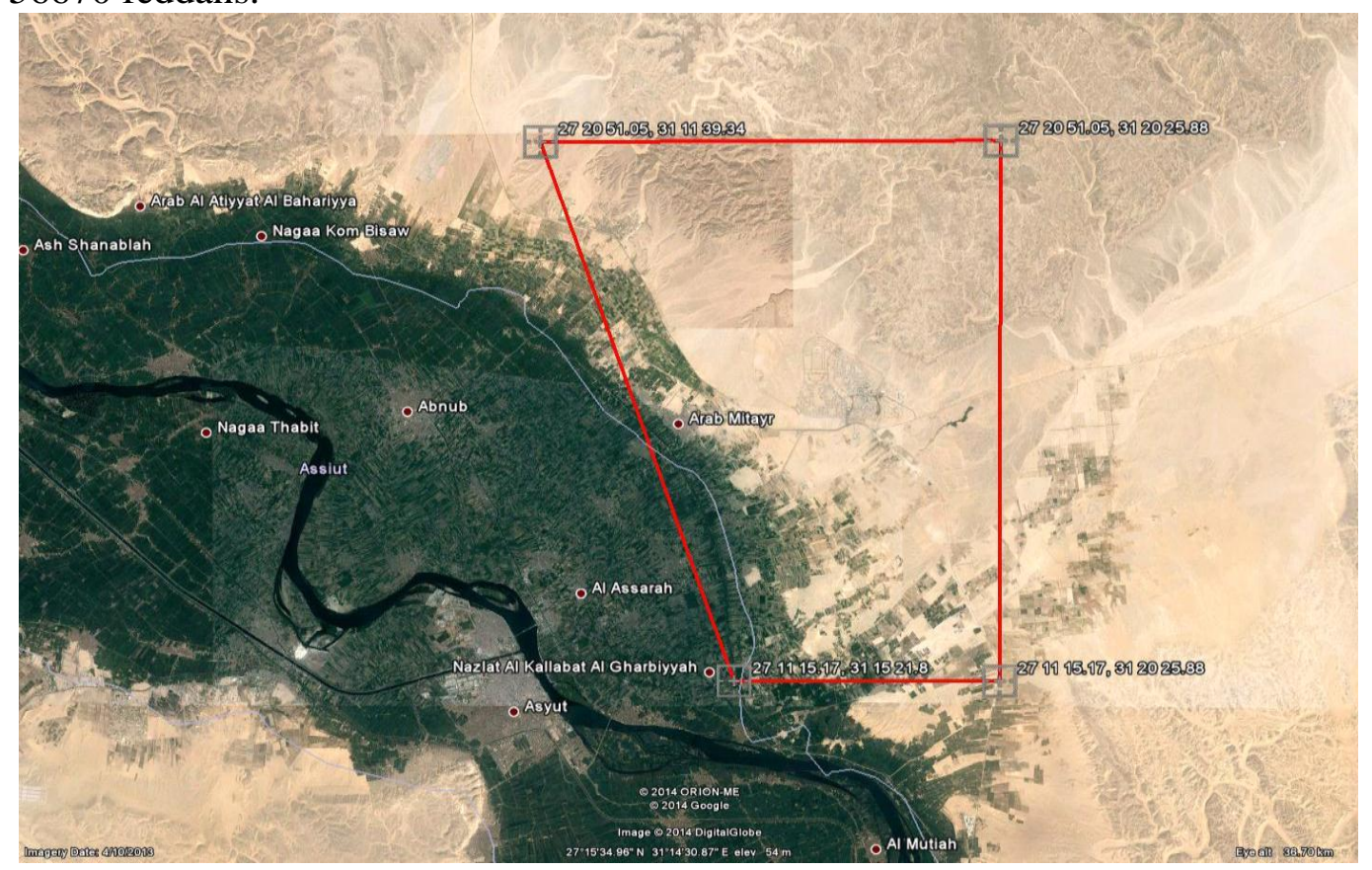

\section{Remote sensing data processing:}

The physiographic units of the study area were based on visual interpretation of Landsat 7 image for year 2000, bands: 2 (green), 3 (red) and 4 (near infrared). The projection of the image was corrected to Egyptian Transverse Mercator (ETM) using ERDAS Imagine.

The interpretation and delineation of this landscape as physiographic units were applied according to the physiographic approach as proposed by Zinck and Valenzuela (1990) using ArcGIS.

\section{Field work:}

Validation and refinement of physiographic map were done during the ground truth to adjust the boundaries between the physiographic units. Ten soil profiles were chosen to represent the different physiographic units and described to the depth of $150 \mathrm{~cm}$ or to the lithic contact, according to USDA (2003). Thirty-one soil samples were collected from the different soil horizons or layers for the purpose of soil analyses. 
Fahmy, F.M.

Laboratory analyses:

Soil samples were air dried, gently crushed, and then sieved through a 2-mm sieve. Fractions less than $2 \mathrm{~mm}$ were subjected to soil analyses. The Chemical and physical properties of the soil samples were determined.

* Particle size distribution was carried out by the pipette method (Piper, 1950).

* Determination of $\mathrm{CaCO}_{3}$ content was done by using the calcimeter according to Black et al. (1965).

* Soil pH was measured in saturated soil paste and Electrical Conductivity (EC) was measured in the soil paste extract by using conductivity bridge (USDA 1954).

* Soluble cations and anions in the saturated soil extract were determined according to Jackson (1967) as follows; $\mathrm{Ca}^{++}$and $\mathrm{Mg}^{++}$by titration using versenate method, $\mathrm{Na}^{+}$and $\mathrm{K}^{+}$by flame photometers, $\mathrm{Cl}^{-}$by the silver nitrate method, $\mathrm{HCO}_{3}{ }^{-}$by titration against $\mathrm{HCl}$ acid, and $\mathrm{SO}_{4}{ }^{=}$by balanced deference.

* Gypsum was determined by the acetone method according to Bower and Huss (1948).

* Soil Taxonomy was performed according to Soil Taxonomy system, USDA (2010).

\section{RESULTS AND DISCUSSION}

\section{Physiographic units:}

Physiographic units were delineated and their legends have been set up as shown in Map (2) and Table (1), associated with the location of the representative soil profiles.

A brief note about the identified physiographic-soil units of the studied area was carried out as follows:

\section{1- The soils of the oldest alluvial terraces:}

This unit covers an area of about 6580 feddans (about $11.61 \%$ of the total area) and represented by soil profile Nos. 7 and 9 . They are mostly distributed in the eastern and southern part of the study area. The field observations (Table 2) show that the soil topography is gently undulating to undulating and soil surface is covered by gravel and some stones. The surface layer is mainly characterized by deep brownish yellow (10YR 6/6, dry) to yellowish brown (10YR 5/6, moist), loamy sand to sandy loam texture, and soil structure is massive in soft to slightly hard consistency. While, the color of subsoil layers is yellowish brown (10YR5/4, dry) to dark yellowish brown (10YR 4/4, moist), sandy loam texture that mixed with many gravel of different sizes (35 to $40 \%$ ). These soils have common to many soft and hard lime accumulations as well as secondary gypsum was observed as few to many soft accumulations. Table (3) reveals that the soils have slightly alkaline reaction $(\mathrm{pH} 7.4$ -7.8 ) and strongly saline (EC 32 to $75 \mathrm{dS} / \mathrm{m}$ ).

Fayoum J. Agric. Res. \& Dev., Vol. 29, No.2, July, 2014 

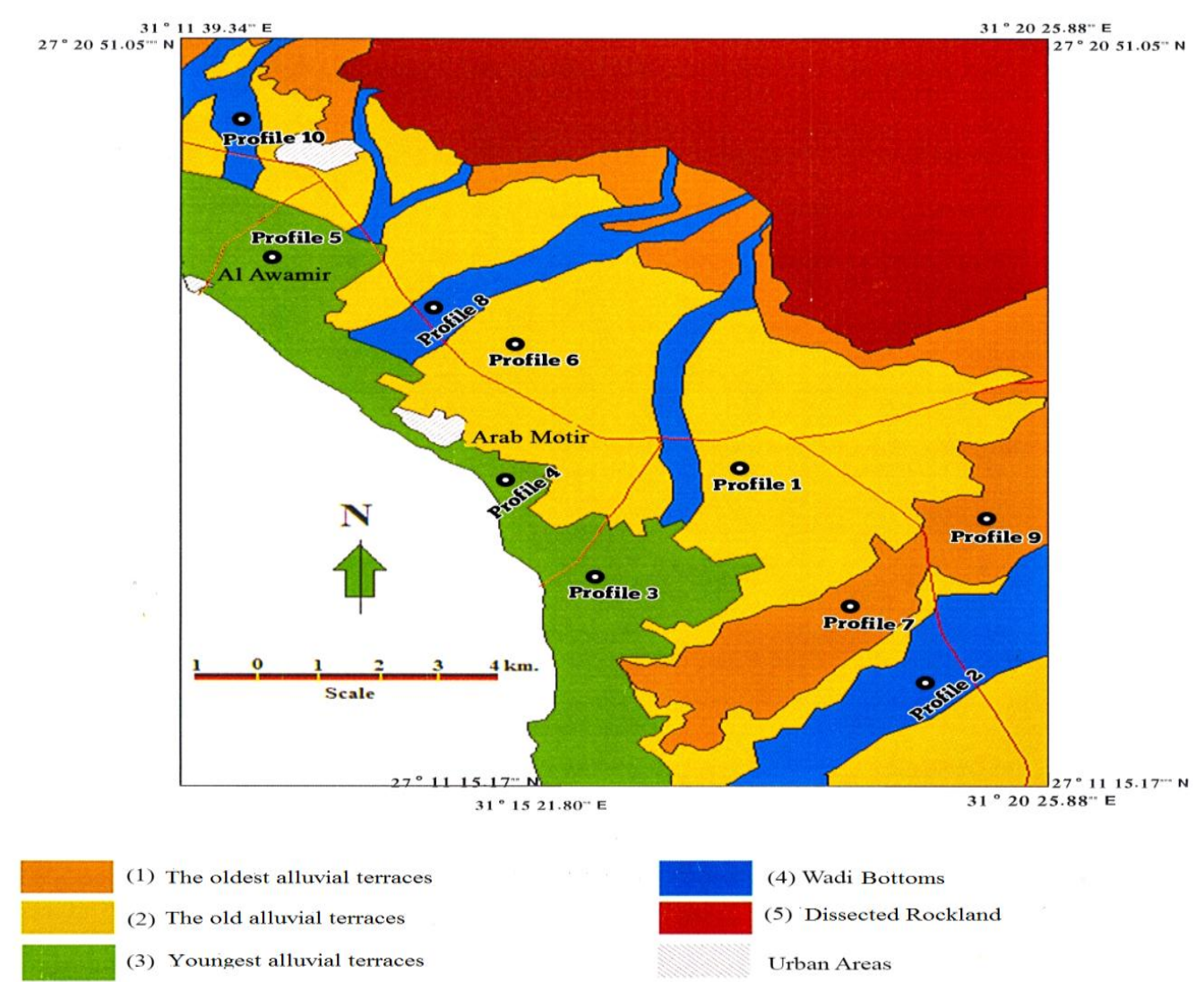

Map (2) Physiographic units of the study area

Table (1) Physiographic Mapping unit areas in the study area

\begin{tabular}{|c|c|c|c|}
\hline N & Physiographic Mapping unit & \multicolumn{2}{|c|}{ Area } \\
\cline { 3 - 4 } o. & Feddans & \% \\
\hline $\mathbf{1}$ & Undulating to gently undulating oldest alluvial terraces & 6580 & 11.61 \\
\hline $\mathbf{2}$ & gently undulating to almost flat old alluvial terraces & 22460 & 39.63 \\
\hline $\mathbf{3}$ & Young alluvial terraces & 11400 & 20.12 \\
\hline $\mathbf{4}$ & Wadi bottoms & 4980 & 8.79 \\
\hline $\mathbf{5}$ & Dissected Rockland & 11250 & 19.85 \\
\hline \multicolumn{2}{|c|}{ Total } & 56670 & 100.00 \\
\hline
\end{tabular}

\section{2- The soils of the old alluvial terraces:}

This unit represents the biggest unit in the studied area since it covers an area of about 22460 feddans (39.63\% of total area), it is located at the center of the studied area and are represented by soil profile Nos. 1 and 6. This unit originated from the run-off of the old natural drainage from the East to the West. The field observations are almost similar to that of the oldest terraces but in relatively low elevation and the soil topography is almost flat to gently undulating. It is mainly characterized by deep brownish yellow (10YR 6/6, dry) to yellowish brown (10YR 5/6, moist), loamy sand to sandy loam texture with

Fayoum J. Agric. Res. \& Dev., Vol. 29, No.2, July, 2014 
Fahmy, F.M.

relatively less gravel content. Soil structure is massive in soft consistency. Also, these soils have common to many soft and hard lime accumulations as well as secondary gypsum was observed as very few to common soft accumulations. Table (3) reveals that the soils have slightly alkaline reaction $(\mathrm{pH} 7.4-7.8)$ and very slightly saline to moderate saline (EC, 2.2 to $15.8 \mathrm{dS} / \mathrm{m}$ ), which become strongly saline in scattered limited zones.

\section{3- Young alluvial terraces soils:}

The area of this physiographic-soil unit is 11400 feddans (about $20.12 \%$ of the total area) and is represented by soil profile Nos. 3, 4 and 5. It extends as a parallel strip with the eastern ridge of the studied soils as a narrow area at the end of the deposition of natural drainage transferred from east to west. This unit is characterized by locally sand encroachment within some rock of original structure, which are transported and deposited by either wind or water action in a limited zone. The field observations (Table 2) show that the soil topography is almost flat to gently undulating and covered by fine and medium gravel. It is mainly characterized by deep yellowish brown (10YR 5/6, dry) to brown (10YR $4 / 3$, moist) in the surface layer, sandy clay loam texture and soil structure is massive in soft to hard consistency. While, the color of subsoil layers is brownish yellow (10YR6/8, dry) to yellowish brown (10YR 5/6, moist), loamy sand or sandy loam texture that mixed with common to many fine and medium gravel (10 to $25 \%$ ). These soils have many soft and hard lime accumulations as well as few soft gypsum accumulations. Table (3) reveals that the soils have slightly alkaline to moderate alkaline reaction $(\mathrm{pH} 7.3-8.3)$ and slightly saline to moderate saline (EC, 2.5 to $10 \mathrm{dS} / \mathrm{m}$ ); among them are scattered spots of very strongly saline reach up to $50 \mathrm{dS} / \mathrm{m}$.

\section{4- Wadi bottoms soils:}

This physiographic unit is found as a narrow strip extends in the direction of the general slopes of the studied area from east to west through the foothills of the rock structures, undulating to gently undulating terraces, gently undulating to almost flat terraces and young alluvial terraces. It is occupied an area of about 4980 feddans (about $8.79 \%$ of the total area) and are represented by soil profile Nos. 2, 8 and 10.

The field observations show that the soil topography is almost flat and covered with scattered natural vegetation and few fine and medium gravel. It is mainly characterized by deep very pale brown (10YR 7/4, dry) to yellowish brown (10YR 5/6, moist) in the surface layer, sandy loam texture and soil structure is single grains to massive in loose to soft consistency.

Fayoum J. Agric. Res. \& Dev., Vol. 29, No.2, July, 2014 
LAND SUITABILITY EVALUATION OF WADI EL ASSIUTY ................. 72

Table(2)

Fayoum J. Agric. Res. \& Dev., Vol. 29, No.2, July, 2014 
Fahmy, F.M.

Table (3): Chemical analysis of the studied soils.

\begin{tabular}{|c|c|c|c|c|c|c|c|c|c|c|}
\hline \multirow{2}{*}{$\begin{array}{c}\text { Prof. } \\
\text { No. }\end{array}$} & \multirow{2}{*}{$\begin{array}{c}\text { Depth } \\
(\mathbf{c m})\end{array}$} & \multirow[b]{2}{*}{ pH } & \multirow{2}{*}{$\begin{array}{c}\mathrm{EC} \\
(\mathrm{dS} / \mathrm{m} \\
)\end{array}$} & \multicolumn{4}{|c|}{ Soluble cation } & \multicolumn{3}{|c|}{ Soluble anions } \\
\hline & & & & $\mathbf{C a}^{++}$ & $\mathbf{M g}^{++}$ & $\mathbf{N a}^{+}$ & $\mathbf{K}^{+}$ & $\mathrm{HCO}_{3}$ & $\mathrm{Cl}^{-}$ & $\mathrm{SO}_{4}=$ \\
\hline & & & Gently & aca & 150 & idulati & olde & errac & & \\
\hline \multirow{3}{*}{7} & $0-40$ & 7.6 & 32.0 & 82.0 & 16.0 & 330.0 & 1.6 & 2.5 & 332.0 & 95.1 \\
\hline & $40-90$ & 7.4 & 75.0 & 241 & 16.9 & 1000.0 & 4 & 2.0 & 90.0 & 270.0 \\
\hline & $90-150$ & 7.4 & 75.0 & 281.0 & 52.1 & 910.0 & 4.3 & 1.5 & 845.0 & 400.0 \\
\hline \multirow{3}{*}{9} & & 7.8 & 11.0 & 43.1 & 12.8 & 70.0 & 0.7 & 2.5 & 72.0 & 52.1 \\
\hline & & 7.6 & 53.0 & 67.6 & 15.7 & 780.0 & 4. & 2.0 & 810.0 & 55.4 \\
\hline & 50 & 7.4 & 50.0 & 239.8 & 39.8 & 410.8 & 2.2 & 2.5 & 427.0 & 257.2 \\
\hline & \multicolumn{10}{|c|}{ Almost flat to gently undulating old terraces } \\
\hline \multirow{3}{*}{1} & & 7.7 & 3.6 & 15.3 & 4.2 & 17.2 & 0.65 & 3.0 & 17.5 & 16.95 \\
\hline & & 7.7 & 3.5 & 15 & 4.7 & 16.1 & & 2.5 & 27.0 & 7.51 \\
\hline & $50-150$ & 7.8 & 5.0 & 15. & 4.3 & 31.6 & 0.7 & 2.0 & 32.0 & 18.02 \\
\hline \multirow{4}{*}{6} & & 7.4 & 2.2 & 9.23 & 1.9 & 12.0 & 0 . & 2.5 & 12.0 & 8.8 \\
\hline & 25 & 7.8 & 15.8 & 238.9 & 28.2 & 120.0 & 1. & 2.5 & 136.0 & 82.1 \\
\hline & & 7.8 & 10.0 & 36.9 & 18.1 & 70.0 & 0.6 & 1.5 & 64.0 & 60.1 \\
\hline & \multicolumn{10}{|c|}{ Young alluvial terraces } \\
\hline \multirow{4}{*}{3} & & 8.2 & 2.5 & 7.1 & 4.7 & 14.0 & 0.20 & 2.5 & 19.0 & 4.56 \\
\hline & $20-70$ & 8.0 & 2.5 & 9.2 & 4.5 & 13.0 & 0 . & 2.5 & 17.0 & 7.43 \\
\hline & $70-100$ & 8.3 & 3.2 & 12.5 & 8.3 & 14.0 & 0.2 & 2.0 & 19.0 & 14.6 \\
\hline & $100-150$ & 8.1 & 2.9 & 9.2 & 7.5 & 14.0 & 0.20 & 1.5 & 16.0 & 13.5 \\
\hline \multirow{3}{*}{4} & & 7.5 & 27.0 & 15 & 37.3 & 198 & 1 & 3.0 & 20.0 & 186.0 \\
\hline & 2 & 7.4 & 50.0 & 2 & 38.8 & 412.8 & 2. & 2.5 & 425.0 & 267.0 \\
\hline & & 7.3 & 38.0 & 205.0 & 30.2 & 320.0 & 1. & 2.0 & 350.0 & 205.0 \\
\hline \multirow{4}{*}{5} & & 8.0 & 10.0 & 44.8 & 44.3 & 11.0 & 6. & 2.5 & 11.0 & 92.8 \\
\hline & & 8.0 & 3.1 & 15 & 2.2 & 15.0 & 0 . & 2.0 & 21.0 & 9.8 \\
\hline & & 7.8 & 1.6 & 7.2 & 1.8 & 7.0 & 0 . & 1.0 & 11.0 & 4.1 \\
\hline & \multicolumn{10}{|c|}{ Wadi bottoms } \\
\hline \multirow{3}{*}{2} & & 7.5 & 6.1 & 29.9 & 4.6 & 31.0 & 0.62 & 3.5 & 32.0 & 30.73 \\
\hline & $30-70$ & 7.7 & 8.2 & 39.2 & 4.5 & 45.0 & 1.10 & 3.0 & 48.0 & 38.86 \\
\hline & & 7.8 & 18.2 & 61 & 20.7 & 151.0 & 1.80 & 2.5 & 156.0 & 76.52 \\
\hline \multirow{3}{*}{8} & & 8.1 & 3.9 & 10.5 & 2.5 & 28.4 & 0. & 2.0 & 28.0 & 10.9 \\
\hline & & 8.0 & 2.1 & 6.5 & 4.6 & 12.0 & 0. & 2.0 & 12.0 & 8.9 \\
\hline & $60-150$ & 8.1 & 1.9 & 6.1 & 3.5 & 10.0 & 0.1 & 1.5 & 10.0 & 8.4 \\
\hline \multirow{3}{*}{10} & & 8.3 & 1.2 & 4.1 & 2.8 & 5.0 & 0.2 & 2.5 & 4.0 & 5.6 \\
\hline & 35 & 8.2 & 1.2 & 7.2 & 1.9 & 3.0 & 0. & 2.0 & 4.5 & 5.8 \\
\hline & $70-150$ & 8.0 & 2.0 & 10.3 & 2.5 & 8.0 & 0.2 & 1.5 & 9.0 & 10.5 \\
\hline
\end{tabular}

Fayoum J. Agric. Res. \& Dev., Vol. 29, No.2, July, 2014 
Table (4): Particle size distribution, $\mathrm{CaCO}_{3}$ and gypsum contents of the studied soils.

\begin{tabular}{|c|c|c|c|c|c|c|c|c|c|}
\hline \multirow{2}{*}{$\begin{array}{l}\text { Prof. } \\
\text { No. }\end{array}$} & \multirow{2}{*}{$\begin{array}{c}\text { Depth } \\
\text { (cm) }\end{array}$} & \multirow{2}{*}{$\begin{array}{c}\text { Gravel } \\
(\%)\end{array}$} & \multicolumn{4}{|c|}{ Particle size distribution } & \multirow{2}{*}{ Texture } & \multirow{2}{*}{$\begin{array}{c}\text { Gypsum } \\
(\%)\end{array}$} & \multirow{2}{*}{$\begin{array}{c}\mathrm{CaCO}_{3} \\
(\%)\end{array}$} \\
\hline & & & C. sand & F. sand & Silt & Clay & & & \\
\hline \multicolumn{10}{|c|}{ Gently undulating to undulating oldest terraces } \\
\hline \multirow{3}{*}{7} & $0-40$ & 35 & 20.33 & 63.10 & 9.73 & 6.84 & LS & 4.1 & 26.0 \\
\hline & $40-90$ & 40 & 7.13 & 67.33 & 13.00 & 12.54 & SL & 13.4 & 16.0 \\
\hline & $90-150$ & 35 & 7.89 & 65.91 & 6.32 & 19.88 & SL & 14.1 & 21.0 \\
\hline \multirow{4}{*}{9} & $0-15$ & 10 & 4.66 & 67.58 & 10.74 & 17.02 & SL & 15.4 & 17.0 \\
\hline & $15-50$ & 10 & 5.05 & 72.77 & 6.90 & 15.28 & SL & 17.7 & 15.0 \\
\hline & $50-150$ & 5 & 2.59 & 70.15 & 8.02 & 19.24 & SL & 13.0 & 9.0 \\
\hline & \multicolumn{9}{|c|}{ Almost flat to gently undulating old terraces } \\
\hline \multirow{3}{*}{1} & $0-17$ & 20 & 115.90 & 67.26 & 7.80 & 9.04 & $\mathrm{LS}$ & 1.0 & 32.8 \\
\hline & $17-50$ & 35 & 23.46 & 61.72 & 8.22 & 6.60 & LS & 0.9 & 32.2 \\
\hline & $50-150$ & 50 & 21.72 & 63.46 & 8.34 & 6.48 & LS & 1.1 & 22.4 \\
\hline \multirow{3}{*}{6} & $0-25$ & 5 & 23.34 & 43.98 & 26.32 & 6.36 & SL & 9.0 & 11.0 \\
\hline & $25-85$ & 5 & 28.06 & 49.61 & 12.46 & 9.87 & SL & 11.9 & 16.2 \\
\hline & $85-150$ & 5 & 33.98 & 54.50 & 5.34 & 6.18 & $\mathrm{~S}$ & 9.7 & 15.4 \\
\hline & \multicolumn{9}{|c|}{ Young alluvial terraces } \\
\hline \multirow{4}{*}{3} & $0-20$ & 10 & 13.84 & 61.44 & 2.80 & 21.92 & SCL & 0.2 & 28.5 \\
\hline & $20-70$ & 15 & 9.90 & 72.70 & 9.78 & 7.62 & LS & 2.1 & 22.4 \\
\hline & $70-100$ & 10 & 7.42 & 71.06 & 10.66 & 10.86 & SL & 2.1 & 35.3 \\
\hline & $100-150$ & 15 & 10.70 & 73.30 & 8.92 & 7.08 & LS & 1.2 & 39.2 \\
\hline \multirow{3}{*}{4} & $0-25$ & 25 & 15.11 & 65.11 & 12.98 & 6.80 & $\mathrm{LS}$ & 1.2 & 16.4 \\
\hline & $25-85$ & 10 & 16.58 & 64.56 & 12.70 & 6.16 & LS & 1.9 & 15.1 \\
\hline & $85-150$ & 15 & 17.42 & 59.68 & 3.82 & 19.08 & SL & 2.3 & 26.3 \\
\hline \multirow{3}{*}{5} & $0-30$ & 10 & 6.20 & 65.00 & 5.44 & 23.36 & SCL & 2.9 & 21.3 \\
\hline & $30-75$ & 15 & 7.67 & 72.97 & 12.02 & 7.34 & LS & 1.4 & 16.0 \\
\hline & $75-100$ & 15 & 20.36 & 59.74 & 14.46 & 5.44 & LS & 2.9 & 21.3 \\
\hline \multirow{4}{*}{2} & \multicolumn{9}{|c|}{ Wadi bottoms } \\
\hline & $0-30$ & 10 & 15.12 & 64.30 & 9.80 & 10.78 & SL & 2.3 & 9.4 \\
\hline & $30-70$ & 35 & 14.74 & 75.28 & 2.66 & 7.32 & S & 0.4 & 1.8 \\
\hline & $70-150$ & 40 & 24.57 & 66.07 & 1.84 & 7.52 & S & 0.2 & 4.5 \\
\hline \multirow{3}{*}{8} & $0-15$ & 7 & 18.47 & 40.43 & 12.52 & 28.58 & SCL & 2.3 & 7.0 \\
\hline & $15-60$ & 25 & 17.89 & 69.99 & 6.56 & 5.56 & $\mathrm{~S}$ & 2.7 & 4.8 \\
\hline & $60-150$ & 20 & 16.07 & 75.55 & 4.22 & 4.16 & S & 1.0 & 3.3 \\
\hline \multirow{3}{*}{10} & $0-35$ & 20 & 17.20 & 72.94 & 3.44 & 6.42 & $\mathrm{~S}$ & 1.0 & 1.7 \\
\hline & $35-70$ & 12 & 31.79 & 52.87 & 6.80 & 8.54 & LS & 1.0 & 3.1 \\
\hline & $70-150$ & 25 & 32.26 & 58.08 & 1.28 & 8.38 & $\mathrm{~S}$ & 0.8 & 3.0 \\
\hline
\end{tabular}

Fayoum J. Agric. Res. \& Dev., Vol. 29, No.2, July, 2014 
Fahmy, F.M.

The texture of subsoil layers is loamy sand or sand with gravel of different sizes (10-40 \% by volume). Table (3) reveals that the soils have slightly alkaline to moderately alkaline reaction $(\mathrm{pH} 7.5-7.8)$ and moderately saline to strongly saline (EC, 6.1 to $18.3 \mathrm{dS} / \mathrm{m}$ ). These properties represented about $75 \%$ of the soils within this unit (profile 2). Also, within this unit, some soils characterized by yellow (10YR 7/6, dry) to light yellowish brown (10YR 6/4, moist), sand textured soil mixed with fine gravel ranged between 7 to $25 \%$ by volume. Soil structure is single grains or massive in loose to soft consistency. These soils have moderately alkaline reaction ( $\mathrm{pH} 8.0-8.3$ ) and slightly saline (EC, 2.0 to $3.9 \mathrm{dS} / \mathrm{m}$ ). Profiles 8 and 10 represented these soils within the physiographic unit and occupies area of about $25 \%$.

\section{5- Dissected Rockland:}

These rock structures are remnants of the former bigger rock structure, which were mostly dissected and eroded. It covers an area of about 11250 faddans (19.85\% of the total area); it is located at the eastern and eastern north side of the studied area in higher level than the other physiographic units. This rock is limestone parent material of the soils that formed by water action in the west of it.

\section{Chemical and physical analyses}

The results of chemical and physical analysis of the soil samples as follows (Tables 3 and 4) show that, the dominant texture is sandy loam and loamy sand with some texture classified as sandy clay loam and sand. The soils of this area have very deep to deep effective soil depth. The EC values ranged from 1.2 $\mathrm{dS} / \mathrm{m}$ up to $75.0 \mathrm{dS} / \mathrm{m}$ with an average of $16.83 \mathrm{dS} / \mathrm{m}$, therefore, the soil salinity classes ranged between slightly saline to moderately and strongly saline soils. The dominant salt is sodium chloride. The $\mathrm{pH}$ values ranged from 7.3 to 8.3 with an average of 7.80. Most of these soils are slightly alkaline to moderately alkaline soils. The total content of calcium carbonate percentage ranged from $9.0 \%$ up to $39.2 \%$ with an average of $25.48 \%$. The gypsum content percentage varied from very low to high and ranged from $0.20 \%$ to $17.7 \%$ with an average of $6.09 \%$. It classified as slightly to moderately gypsiric soils and only small area classified as strongly gypsiric soils.

\section{Soil Taxonomic units:}

Soils in different physiographic units were classified to the family level by using the Soil Taxonomy (USDA, 2010). The taxonomic units are relating to the Aridisols, and Entisols soil orders. The derived taxonomic units were combined with the physiographic units in Table 5.

Fayoum J. Agric. Res. \& Dev., Vol. 29, No.2, July, 2014 
LAND SUITABILITY EVALUATION OF WADI EL ASSIUTY.

Table (5): Physiographic units versus soil taxonomy in the studied soil profiles.

\begin{tabular}{|c|c|c|}
\hline Physiographic units & $\begin{array}{l}\text { Profile } \\
\text { No. }\end{array}$ & Soil Taxonomic units \\
\hline \multirow{2}{*}{$\begin{array}{l}\text { Undulating to gently } \\
\text { undulating oldest } \\
\text { terraces }\end{array}$} & 7 & $\begin{array}{c}\text { Typic Calcigypsids, loamy-skeletal, mixed, } \\
\text { hyperthermic. }\end{array}$ \\
\hline & 9 & $\begin{array}{c}\text { Typic Calcigypsids, coarse-loamy, gypsic, } \\
\text { hyperthermic. }\end{array}$ \\
\hline \multirow{2}{*}{$\begin{array}{l}\text { Almost flat to gently } \\
\text { undulating old } \\
\text { terraces }\end{array}$} & 1 & $\begin{array}{c}\text { Typic Haplocalcids, sandy-skeletal, mixed, } \\
\text { hyperthermic. }\end{array}$ \\
\hline & 6 & $\begin{array}{c}\text { Typic Calcigypsids, coarse-loamy, mixed, } \\
\text { hyperthermic. }\end{array}$ \\
\hline \multirow{3}{*}{$\begin{array}{l}\text { Young alluvial } \\
\text { terraces }\end{array}$} & 3 & \multirow{3}{*}{$\begin{array}{l}\text { Typic Haplocalcids, sandy, mixed, } \\
\text { hyperthermic. }\end{array}$} \\
\hline & 4 & \\
\hline & 5 & \\
\hline \multirow{3}{*}{ Wadi bottoms } & 2 & $\begin{array}{c}\text { Typic Torriorthents, sandy-skeletal, mixed, } \\
\text { hyperthermic. }\end{array}$ \\
\hline & 8 & \multirow{2}{*}{$\begin{array}{l}\text { Typic Torriorthents, sandy, mixed, } \\
\text { hyperthermic. }\end{array}$} \\
\hline & 10 & \\
\hline
\end{tabular}

The main soil attributes that are required for defining each taxonomic unit are described as follows:

\section{Aridisols:}

The soils of this order have one or more diagnostic horizon within $100 \mathrm{~cm}$ from the surface and including the following families:

\section{Typic Clacigypsids, loamy-skeletal, mixed, hyperthermic.}

These soils have gypsic and calcic horizons, which developed together in the soil strata. The gypsic horizon had the priority for naming the suborder as Gypsids and the calcic horizon characterizes the soil great group as Calcigypsids. The subgroup was specified as "Typic", since it represents the central concept of its great group. The gypsum content in this unit ranges from 4.1 to $14.1 \%$ and the highest values are found in the subsurface layers, while the total calcium carbonate content ranges from 16 to $26 \%$ (10 to $15 \%$ by volume identifiable lime) and the highest values are found in the surface layers. As the control section $(25-100 \mathrm{~cm})$ is dominated by the sandy loam texture with coarse fragments from 35 to $50 \%$ by volume, the average weight of gypsum content is less than $15 \%$ and the mean annual soil temperature is more than $22 \mathrm{C}$, the soil family was described as loamy-skeletal, mixed and hyperthermic for particle-size, mineralogy and soil temperature regime, respectively. These soils were identified in the gently undulating to undulating oldest terraces. This taxonomic unit was represented by soil profile 7 .

\section{Typic Calcigypsids, coarse-loamy,mixed, hyperthermic.}

These soils have gypsic horizon developed throughout the solum $(9.0 \%$ to $11.9 \%$ gypsum and $5 \%$ to $10 \%$ by volume as secondary visible gypsum). Calcic horizon also developed within the soil control section $\left(11.0 \%\right.$ to $16.2 \% \mathrm{CaCO}_{3}$ equivalent and $10 \%$ by volume identifiable lime). Since the control section is

Fayoum J. Agric. Res. \& Dev., Vol. 29, No.2, July, 2014 
dominated by sandy loam, the soils are grouped as coarse-loamy, mixed. They are represented by profile 6 as minor soils (gently undulating to almost flat old terraces).

Typic Calcigypsids, coarse-loamy, gypsic, hyperthermic.

The soil of this unit have gypsic horizon developed throughout the solum including 13.0 to $17.7 \%$ gypsum, and calcium carbonate that ranges from 9 to $17 \%$ equivalent and $10 \%$ by volume identifiable lime. As the control section is dominated by sandy loam and the average weight of gypsum content is $15 \%$ or more, the soil family was described as coarse-loamy, gypsic, hyperthermic. They are represented by soil profile 9 (gently undulating to undulating oldest terraces) as minor soils.

\section{Typic Haplocalcids, sandy, mixed, hyperthermic.}

These soils have calcic horizon developed throughout the solum (15.1 to 39.2 $\% \mathrm{CaCO}_{3}$ equivalent and $10 \%$ by volume identifiable lime by volume, having simple soil profiles (Haplocalcids). Since the soil control section is dominated by loamy sand, they are categorized as sandy at the family level. These soils were identified in the young alluvial terraces (profiles 3, 4, 5).

\section{Typic Haplocalcids, sandy-skeletal, mixed, hyperthermic}

The control section of this Haplocalcids have loamy sand texture with gravel of 35 to $50 \%$ by volume. They were represented as dominant soils in the old terraces (profile 1).

\section{b) Entisols:}

Smith (1986) considered the Entisols as azonal soils, lacking subsurface diagnostic horizons. They are either loosing material too rapidly through truncation or receiving additions too rapidly for horizons to form. Climate is shown only at the great group level because suborder level is first sorted out according to the reasons as why they had no subsurface diagnostic horizon. In the current study, two soil families were identified as follow:

\section{Typic Torriorthents, sandy, mixed, hyperthermic.}

These soils are rather $\underline{\text { Orthents }}$ that were transported and deposited by water action. They have coarse texture in the sub-surface soil layers. At the family level, these soils are characterized as mixed being of less than $90 \%$ silica minerals (quarts). These soils were identified in the wadi bottom unit and were represented by profiles 8 and 10.

\section{Typic Torriorthents, sandy skeletal, mixed, hyperthermic.}

These soils have sandy loam surface layers of $30 \mathrm{~cm}$ thickness and sandy subsoil layers with gravel of 35 to $40 \%$. They were represented by soil profile No 2 in the wadi bottoms physiographic unit.

\section{Land Suitability:}

The current and potential suitability of the studied soils for irrigated agriculture was estimated by matching between the present soil characteristics and their ratings are calculated by using the parametric system outlined by Sys and Vereheye (1978), as shown in Table (6). The obtained results indicate that all soils have no to slight intensity of limitations for wetness, soil depth, calcium carbonate and gypsum contents. Also, data show that most of the studied soils are suffering

Fayoum J. Agric. Res. \& Dev., Vol. 29, No.2, July, 2014 
LAND SUITABILITY EVALUATION OF WADI EL ASSIUTY ................. 78 from some limiting factors, i.e., topography $(\mathrm{t})$, soil texture including gravel $\left(\mathrm{s}_{1}\right)$ and salinity \& alkalinity (n).

Table(6)

Fayoum J. Agric. Res. \& Dev., Vol. 29, No.2, July, 2014 
Current land suitability:

* The oldest terraces soils

The current suitability class is not suitable $(\mathrm{N} 1)$, where $\mathrm{Ci}$ values range from 14.8 to 19.7 . These soils have a severe intensity of salinity and alkalinity, and a moderate intensity of topography and texture limitations.

* The old terraces soils

The current suitability class is marginally suitable (S3) where Ci values range from 36.5 to 40.3 . These soils have a moderate to severe intensity of texture and a slight intensity of topography limitations.

* The young alluvial terraces soils

The current suitability class is marginally suitable (S3) where $\mathrm{Ci}$ values range from 30.5 to 43.7 . These soils have a moderate intensity of texture and non to moderate intensity of salinity and alkalinity limitations.

* Wadi bottom soils

The current suitability class is moderately suitable (S2) to marginally suitable (S3) where $\mathrm{Ci}$ values range from 40.5 to 54.0 . These soils have a moderate to severe intensity of texture limitations.

\section{Potential land suitability:}

A potential suitability term refers to the suitability of units after specified major improvements have been completed where necessary (FAO, 1976).

Land improvements are required to correct or reduce the severity of limitations exiting in the area under consideration. Examples are as follows:

a) Leveling of undulating surfaces,

b) Leaching of salinity and reclamation of alkalinity existing in the soils,

c) Construction of good drainage systems to drain or to lower the saline ground water table,

d) Application of chemical and organic fertilizers, green manures and soil conditioners to increase soil fertility and to improve the physical and chemical soil properties,

e) Application of modern irrigation systems, such as drip and sprinkler, to save irrigation water and to prevent the formation or the rise of ground water table, and.

f) Construction of natural and/or artificial windbreaks to protect the farms and to prevent or reduce the wind erosion and deposition hazard of loose sand, which causes aserious damage to agriculture, as well as to buildings and other existing infrastructures.

The soils of the studied area can be potentially classified as one class, which is moderately suitable (S2) where $\mathrm{Ci}$ ranges from 50.6 to 67.5. The soils have moderate to slight intensity of texture, calcium carbonate and /or gypsum limitations. However, it could be recommended that this promising area needs more detailed studies for its land resources to enrich the area database and identify its potential suitability under a well defined land utilization types.

Fayoum J. Agric. Res. \& Dev., Vol. 29, No.2, July, 2014 
REFERENCES

Afify, A. A. 2009. Land resources evaluation of the paleodrainage Delta in western desert of Egypt using remote sensing data. Egypt. J. Remote Sensing \& Space Sci., V.12, pp. 3-26.

Bower, C.A. and Huss, R.B. 1984. Rapid conduct metric method for estimating gypsum in soils. Soil Sci., 66: 199.

Black, C. A.; Evans D.D.; Ensminger L.E.; White J.L. and Clark F.E. 1965. Methods of Soil Analysis. Part 2 Am. Soc. of Agron. Inc., Madison, Wisconsin, USA. pp 1389-392.

FAO, 1976. A Frame work For Land evaluation. Soil Bulletin No.32, FAO Rome, Italy.

Goosen, D. 1967. Aerial photo interpretation in soil survey. FAO Soil Bull. No. 6, FAO, Rome, Italy.

Hudson B. D. 1992. "The soil survey as paradigm-based science", Soil Sci. Soc. Am. J. 56: 836-841.

Jackson, M. L. 1967. Soil chemical analysis. Prentice- Hall, Inc. N. J. USA.

Jenny, H. 1941. Factors of soil formation - a system of quantitative pedology. New York: McGraw-Hill

Piper, C. S., 1950. Soil and plant analysis. Int. Sci. Publishers, Inc. New York, USA.

Rashed, M.; Idris, Y. and Shaban, M. 2006. Integrative approach of GIS and Remote Sensing to represent the hydrogeological and hydrochemical conditions of Wadi Qena-Egypt. The $2^{\text {nd }}$ International Conf. on Water Resources \& Arid Environment (ICWRAE), King Saud University, Riyadh, Saudi Arabia, 26-29 November 2006.

Smith, G. 1986. The Guy Smith interviews: Rational for concepts in Soil Taxonomy. S.M.S.S., Tech. Monograph No. 11, Washington, D.C., USA.

Sys, C. and Verhey, W. 1978. An attempt to evaluation of physical characteristics for irrigation; according to the FAO framework for land evaluation, International Training Center for Post Graduate Soil.

USDA, 1954. Diagnosis and improvement of saline and alkali soils. United States Department of Agriculture (USDA), Handbook No. 60, U.S. Govt. Printing Office, Washington, D. C. USA.

USDA, 1969. Diagnosis and improvement of saline and alkali soils. United States Salinity Laboratory Staff, (USDA), Handbook $2^{\text {nd }}$ Ed. 60. USA.

USDA, 2003. Soil Survey Manual. United States Department of Agriculture, Handbook 18, U. S. Gov. Print. Off, Washington, D.C., USA.

USDA, 2010. Keys to Soil Taxonomy. ${ }^{11 \text { th }}$ Edition, United States Department of Agriculture, (USDA), USA.

Zinck, J.A. and Valenzuela, C. R., 1990. Soil geographic database: structure and application examples. ITC j., 3: 270.

Zhu, A. X.; Hudson, B.; Burt, J.; Lubich, K.; \& Simonson, D. 2001. Soil mapping using GIS, expert knowledge, and fuzzy logic. Soil Science Society of America Journal 65(5):1463-1472.

Fayoum J. Agric. Res. \& Dev., Vol. 29, No.2, July, 2014 
تقييم صلاحية أراضى وادى الأسيوطي بالصحراء الشرقية بمحافظة أسيوط - مصر باستخدام معلومات

الإستشعار من بعد

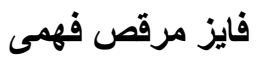

معهد بحوث الأراضى والمياه والبيئة ، مركز البحوث الزراعية، الجيزة، مصر

تقع منطقة الدر اسة فى الصحر اء الثرقية من الجزء الاوسط لوادى النيل وتقدر مساحتها الكلية

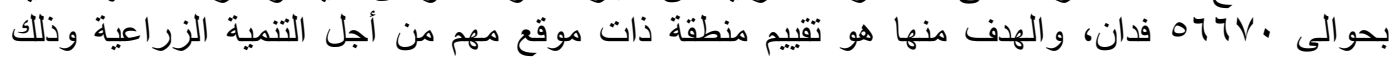

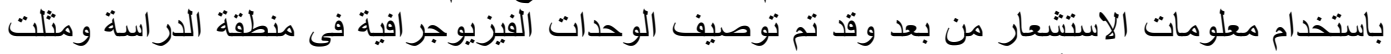

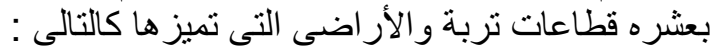

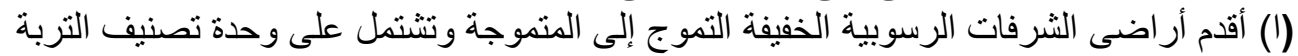

Typic Clacigypsids, loamy-skeletal, mixed, hyperthermic.

و التى ترتبط جزئيا مع الوحدة التصنيفية

Typic Clacigypsids, coarse-loamy, gypsic, hyperthermic.

(ب) أراضى الثرفات الرسوبية القديمة الخفيفة التموج إلى الثبه مستوية وتشنمل على وحدة الأراضى

Typic Haplocalcides, sandy-skeletal, mixed, hyperthermic.

كار اضى سائدة بتخللها بنسبة قلبلة الوحدة التصنيفية

Typic Clacigypsids, coarse-loamy, mixed, hyperthermic.

$$
\text { (ج) السهول الرسوبية الحديثة وتتنمل على وحدة تصنيف التربة }
$$

Typic Haplocalcids, sandy, mixed, hyperthermic.

(د) أر اضى قيعان الوديان وتتنمل على الوحدتين التصنيفيتين

Typic Torriorthents, sandy-skeletal, mixed, hyperthermic.

Typic Torriorthents, sandy, mixed, hyperthermic.

كأر اضى سائدة بتخلاها بنسبة قليلة

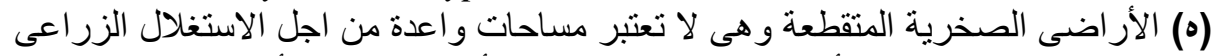

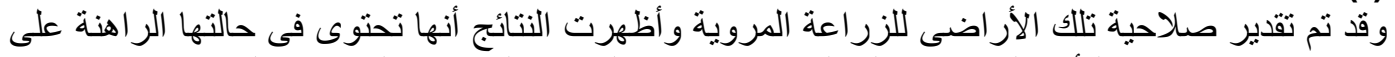

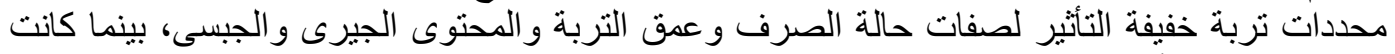

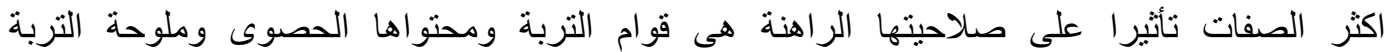

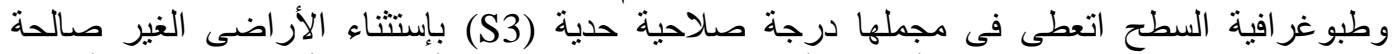

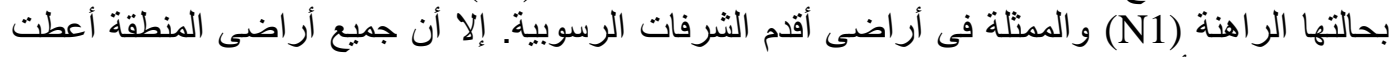

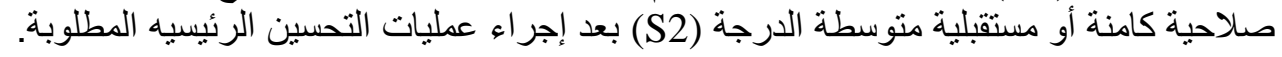

Fayoum J. Agric. Res. \& Dev., Vol. 29, No.2, July, 2014 